\title{
CORTICOTROPIN-RELEASING FACTOR IMMUNOREACTIVITY IS WIDELY DISTRIBUTED WITHIN THE CENTRAL NERVOUS SYSTEM OF THE RAT: AN IMMUNOHISTOCHEMICAL STUDY ${ }^{1}$
}

\author{
S. CUMMINGS, ${ }^{*}$ R. ELDE, ${ }^{*, 2}$ J. ELLS, \\ ${ }^{*}$ Department of Anatomy, University of Minnesota, Minneapolis, Minnesota 55455 and $\ddagger$ ImmunoNuclear Corporation, \\ Stillwater, Minnesota 55082
}

Received October 1, 1982; Revised January 13, 1983; Accepted January 18, 1983

\begin{abstract}
The discovery of a 41-amino acid peptide with potent corticotropin-releasing factor properties has prompted a search for neurons that contain this substance and potentially utilize it in intercellular communication. The present study utilized immunohistochemical methods and an antiserum directed against a synthetic replica of ovine corticotropin-releasing factor. The rat hypothalamus was found to contain striking immunoreactive groups of neuronal perikarya within the paraventricular, periventricular, and anterior hypothalamic nuclei, some of which are likely to project to the external layer of the median eminence and thereby comprise a hypophysiotropic system. Certain other hypothalamic nuclei, as well as many other regions of the central nervous system, were found to contain corticotropin-releasing factor-immunoreactive neurons. Among the most prominent of these were neurons in the bed nucleus of stria terminalis, the central nucleus of the amygdala, the region of the dorsal raphe, locus ceruleus, the external cuneate nucleus, and the medullary reticular formation. Thus, corticotropin-releasing factor, like many other neurohormones and peptides, may participate in neuroendocrine regulation as well as play a role as a neurotransmitter-like substance in numerous extrahypothalamic circuits.
\end{abstract}

The proposal by Harris in 1948 that hypothalamic neurons produce discrete factors that regulate the release of the hormones of the anterior lobe of the pituitary gland led to an intensive biochemical search in order to isolate, characterize, and synthesize these factors. Although the existence of corticotropin (ACTH)-releasing factor (CRF) was among the first to be established (Guillemin and Rosenberg, 1955; Saffran and Schally, 1955), its complete characterization and synthesis eluded discovery until the recent reports of Vale and colleagues (Spiess et al., 1981, Vale et al., 1981). These investigators presented the primary structure of a 41-amino acid peptide isolated from ovine hypothalamic extracts that possesses potent ACTH- and $\beta$-endorphin-releasing activity in vitro as well as in vivo (Rivier et al., 1982). The in vitro activity of an independently synthesized replica of

\footnotetext{
${ }^{1}$ We gratefully acknowledge the expert assistance of M. Frick and T. Mullet in technical aspects of this study, W. Gutzmer for photography, and J. Mattson for manuscript preparation. These studies were supported in part by National Institute on Drug Abuse Grant DA 02148 (R. E.) and ImmunoNuclear Corporation.

${ }^{2}$ To whom correspondence should be addressed at Department of Anatomy, University of Minnesota, 321 Church Street S.E., Minneapolis, MN 55455.
}

this peptide has also been confirmed (Turkelson et al., 1982).

In spite of the elegant success of the endeavor to characterize CRF, it remains to be established that the peptide characterized by Vale and colleagues is the physiologically relevant factor in the regulation of $\mathrm{ACTH}$ release. It has been argued that, in order for a substance to be a physiologically relevant releasing factor, it must be contained within a system of nerve terminals within the external layer of the hypothalamic median eminence where, upon release, it might gain access to the primary plexus of the hypothalamo-hypophyseal portal vasculature (Elde and Hökfelt, 1979). Toward this end, immunohistochemical localization studies have contributed important information concerning the distribution of a variety of neuropeptides at the neuronal level; thus, the present sludy was undertaken to determine the configuration of neuronal circuits that contain CRF immunoreactivity. The findings support the notion that immunoreactivity similar to that of the 41 -amino acid CRF is prominent in nerve fibers and terminals of the rat median eminence, is found within neuronal cell bodies known to project to this region, and, finally, is, as in the case of many other neuropeptides, widely distributed in neurons that have no direct neuroendocrine role. Portions of this 
study have been reported in abstract form (Cummings et al., 1982). (During preparation of this paper, other investigators, using immunohistochemical techniques, reported the occurrence of CRF immunoreactivity in hypothalamic neurons as well as in terminals within the median eminence (Bloom et al., 1982; Bugnon et al., 1982a, b; Paull et al., 1982; Tramu and Pillez, 1982) and in extracts of rat hypothalamus (Moldow and Fischman, 1982) and extrahypothalamic brain regions (Fischman and Moldow, 1982) by radioimmunoassay.)

\section{Materials and Methods}

To investigate the distribution of CRF throughout the brain, normal $(n=3)$ or colchicine-treated ( $50 \mu \mathrm{g}$; right lateral ventricle; 48 -hr survival; $n=16$ ) male albino rais (body weight 160 to $200 \mathrm{gm}$ ) were anesthetized with chloral hydrate $(350 \mathrm{mg} / \mathrm{kg}$ of body weight, i.p.) and perfused transcardially with a fixative consisting of 200 $\mathrm{ml}$ of $4 \%$ paraformaldehyde in $0.1 \mathrm{M}$ phosphate buffer, $\mathrm{pH} 6.5$, followed by $500 \mathrm{ml}$ of $4 \%$ paraformaldehyde in 0.1 м borate buffer, $\mathrm{pH} 11$ (Berod et al., 1981). The brains were immersed in the same fixative for $90 \mathrm{~min}$ and stored in 5\% sucrose in $0.1 \mathrm{~m}$ Sorenson's phosphate buffer, $\mathrm{pH}$ 7.3 , for at least $24 \mathrm{hr}$. Tissue was frozen and sectioned at $75 \mu \mathrm{m}$ on a sliding microtome in a coronal plane and processed by the peroxidase-antiperoxidase (PAP) method of Sternberger (1979) modified for free-floating sections (Grzanna et al., 1978; Haber and Elde, 1982).

Antiserum to CRF was produced by rabbits in response to a synthetic ovine CRF-methylated serum albumin complex (ImmunoNuclear Corp., Stillwater, MN). Sections for the immunoperoxidase method were incubated overnight at $4{ }^{\circ} \mathrm{C}$ with a $1: 750$ dilution of primary antiserum in $0.3 \%$ Triton $\mathrm{X}-100$ in phosphate-buffered saline (PBS; $\mathrm{pH}$ 7.3) with $1 \%$ normal sheep serum (hereafter called "antiserum diluent"). The tissue was rinsed in several changes of PBS for 20 min and incubated in sheep anti-rabbit IgG (1:300 in antiserum diluent; Antibodies Inc., Davis, CA) for $1 \mathrm{hr}$ at room temperature with rabbit PAP (1:500 in antiserum diluent; N. L. Cappel Laboratories, Cochranville, PA). After rinsing with Tris $(0.05 \mathrm{M}$; $\mathrm{pH} 7.6)$ the tissue was incubated in $3,3^{\prime}$-diaminobenzidene tetrahydrochloride $(0.5 \mathrm{mg} / \mathrm{ml}$ in Tris buffer containing $0.01 \% \mathrm{H}_{2} \mathrm{O}_{2}$ ) for approximately $20 \mathrm{~min}$ at room temperature. The sections were rinsed and mounted on gelatin-coated slides, allowed to dry overnight at $40^{\circ} \mathrm{C}$, dehydrated, and coverslipped with Entellan.

Specificity controls for the immunohistochemical localizations were obtained by incubating sections adjacent to those above with antiserum that had been pretreated overnight with an excess of synthetic CRF (13 $\mu \mathrm{g}$ of $\mathrm{CRF} / \mathrm{ml}$ of diluted CRF antiserum). All of the staining observed was found to represent immunohistochemically specific localizations, because no staining was found in structures on the sections which served as absorption controls (see Figs. 2 and 13). Furthermore, the PAP procedure as outlined above was conducted on filter papcr (Whatman no. 1) upon which various synthetic peptides had been immobilized with vapor-phase formaldehyde fixation according to the method of Larsson (1981). The peptides immobilized and tested included ovine CRF, Lys ${ }^{8}$-vasopressin, $\mathrm{Arg}^{8}$-vasopressin, oxytocin, dynorphin-(1-8), dynorphin-(1-13), dynorphin-(1-17), bovine neurophysin I, and bovine neurophysin II. Each peptide was tested at concentrations from $10 \mathrm{nmol}$ to 10 $\mathrm{pmol} / 2 \mu \mathrm{l}$ of blot. The antiserum to CRF stained blots containing as little as $10 \mathrm{pmol}$ of CRF. In contrast, the antiserum did not stain blots containing $10 \mathrm{nmol}$ of the other peptides listed above. Thus, cross-reactivity with these other peptides, if it exists, is less than $0.1 \%$.

Sections processed by the PAP method were examined and photographed with an Olympus brightfield microscope. Determination of nuclear boundaries was aided by inspection of immunostained sections after counterstaining with methyl green and cresyl violet. The rat brain atlases of König and Klippel (1967) and Pellegrino et al. (1979) were consulted, as were studies of certain nuclear regions (Valverde, 1962; Swanson, 1976; Loewy and Saper, 1978; Sakai et al., 1978; Grzanna and Molliver, 1980; King, 1980; Swanson and Kuypers, 1980; Alonso, 1981; Kohler and Steinbusch, 1982; McDonald, 1982; Neiuwenhuys et al., 1982; Roberts et al., 1982; Sawchenko and Swanson, 1982).

\section{Results}

CRF-immunoreactive structures were found in many regions of the central nervous system of rats examined in this study. The density of immunoreactive structures and intensity of staining varied according to the region of the nervous system as well as the location of cell bodies or fibers within particular nuclei. Both fibers and cell bodies varied in density from occasional, isolated structures to very dense and entangled networks. Immunostained fibers varied in length, and in diameter from fine to medium, with the majority of fibers being studded with varicosities. The varicosities appeared either as large and irregular beads or smaller, more rounded structures. CRF-immunoreactive neurons were polymorphic and variable in size. CRF immunoreactivity within cell bodies was most apparent in tissue from colchicine-treated ani-

Figures 1 to 5 . Immunoperoxidase photomicrographs of 75- $\mu \mathrm{m}$ frozen sections from colchicine-treated (Figs. 1, 2, 4, and 5) and normal (Fig. 3) rats of telencephalic regions in the coronal plane after incubation with antiserum to CRF (Figs. 1, 3 to 5) and with control CRF-absorbed serum (Fig. 2). The arrowhead and the small arrow (upper left) indicate dorsal and medial, respectively.

Figure 1. Neurons within the central nucleus of the amygdala stained densely for CRF immunoreactivity. ST, stria terminalis. Magnification $\times 110$.

Figure 2. After incubation with control CRF-absorbed serum, neither immunoreactive cells nor fibers could be seen in the central nucleus of the amygdala in a section adjacent to that in Figure 1. ST, stria terminalis. Magnification $\times 110$.

Figure 3. CRF-immunoreactive fibers within organum vasculosum lamina terminalis. *, capillaries. Magnification $\times 210$.

Figure 4. Four cells and a fiber grouping immunostained for CRF within the horizontal limb of the diagonal band of Broca. Magnification $\times 220$.

Figure 5. Cluster of dorsoventrally oriented immunoreactive neurons located at the medial edge of the lateral septal nucleus after incubation with antiserum to $\mathrm{CRF}$. Magnification $\times 220$. 


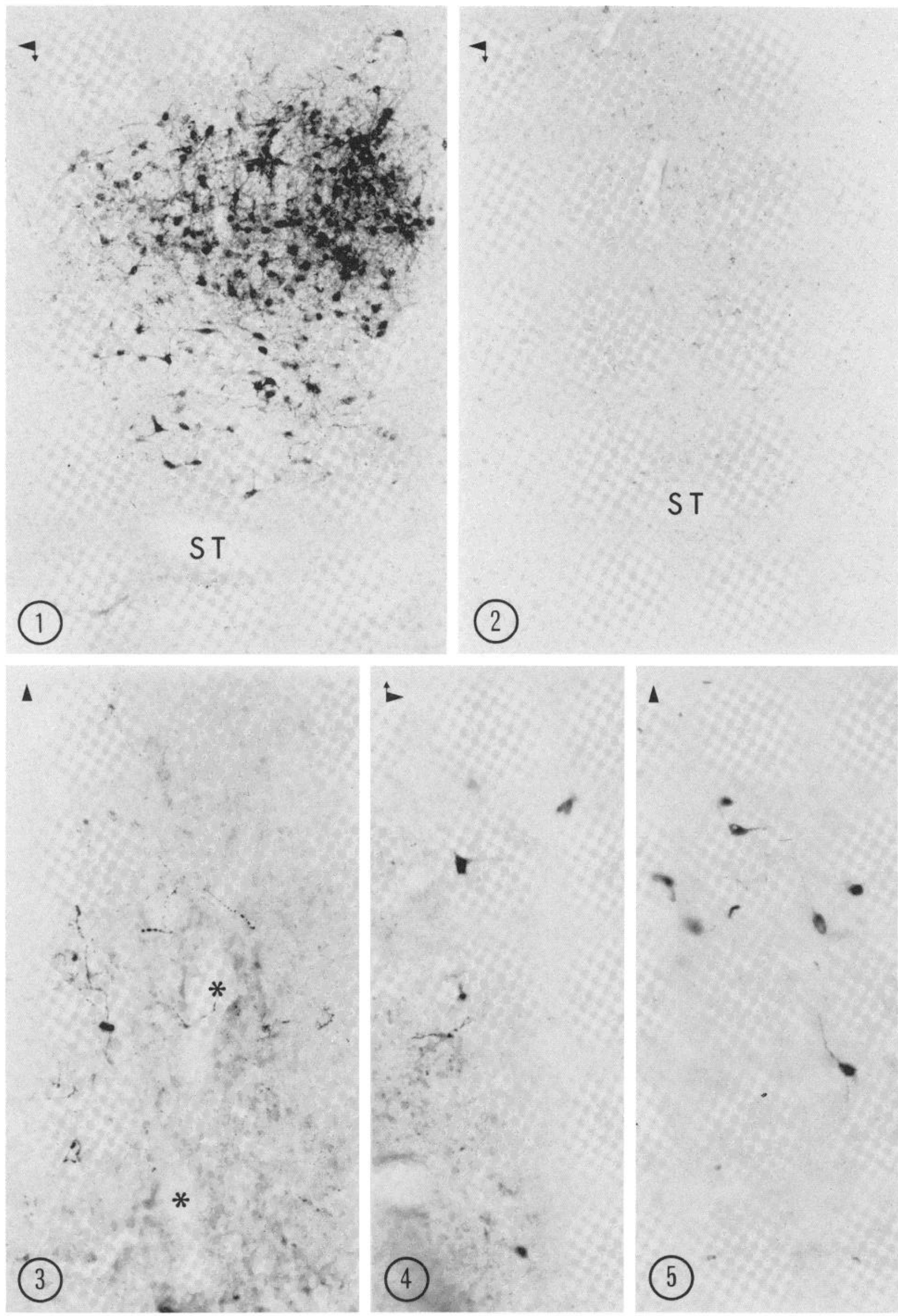

Figures 1 to 5 
mals. CRF immunoreactivity within neuronal fibers was more readily observed in tissue from normal animals.

\section{Telencephalon}

Amygdala. CRF immunostaining in the amygdaloid complex was restricted to the compact and well defined central nucleus. The CRF-immunostained neurons were densely stained and rounded or pyramidal in shape, and they exhibited two to four dendrites (Fig. 1).

Nucleus of the diagonal band of Broca. This area contained CRF-immunoreactive neurons of variable staining intensity. The polymorphic cells as well as scattered, medium-diameter, beaded fibers were located medially in the horizontal limb and merged caudally into the medial forebrain bundle (Fig. 4).

Lateral septal nucleus. Several medium-sized cells with moderate CRF immunoreactivity were located near the medial edge in sections of this nucleus (Fig. 5), whereas very lightly stained cells were found more laterally. Dendritic processes were not prominent.

Medial septal nucleus. Short, scattered CRF-immunoreactive fibers of medium diameter were present in this area, although no stained cell bodies were observed.

Olfactory tubercle. Fine, scattered fibers immunostained for CRF were present in this field, but immunoreactive cells were absent.

Region of the anterior commissure. In the region of the anterior commissure many neurons and mediumdiameter beaded fibers of the bed nucleus of the stria terminalis exhibited CRF immunoreactivity. These structures were first apparent rostrally as cells on the ventral tip of the lateral ventricle (Fig. 6). Medially, CRF-immunoreactive neurons merged with similarly stained cells of the anterior preoptic nucleus. At the level of the crossing of the commissure, neurons of the bed nucleus of the stria terminalis were intensely immunostained and densely packed (Figs. 7 and 8). CRF-immunostained cells were also present in the subcommissural portion of the bed nucleus of the stria terminalis (Figs. 6 to 8 ). Caudal to the crossing of anterior commissural fibers, these subcommissural neurons and fibers appeared to become continuous laterally with the supracommissural portion of the nucleus (Fig. 8). CRH'-immunostained neurons were also widespread ventral to the crossed commissure within the medial forebrain bundle and the medial and lateral preoptic nuclei (Figs. 7 and 8 ). The medial preoptic nucleus contained CRFimmunoreactive neurons as a moderately compact aggregation of rounded, pyramidal, and spindle-shaped cells similar to those of the bed nucleus of the stria terminalis and the anterior preoptic nucleus.

Organum vasculosum lamina terminalis. Intensely stained CRF-immunoreactive fibers with coarse, irregularly shaped varicosities were present in this highly vascularized area (Fig. 3 ).

\section{Diencephalon}

Hypothalamic periventricular nucleus. CRF-immunoreactive cells of this nucleus were intensely stained (Fig. 9). These periventricular neurons were rounded or elongated in profile, lying in a narrow band very close to the ependymal wall of the ventral half of ventricle III, particularly at the caudal level of the optic chiasm. Some cells closely approached the ventral tip of the ventricle but did not extend into the suprachiasmatic nucleus. Dendrites were few but appeared to have some dorsoventral orientation. Medium-diameter fibers were always more demonstrable in normal, as opposed to colchicinetreated, animals.

Hypothalamic paraventricular nucleus. This nucleus contained the most striking group of CRF-immunoreactive neurons in the brain (Fig. 11). Cells of the lateral and medial parvocellular divisions were intensely stained and densely packed (Fig. 12). CRF immunostaining was observed in cells of these divisions even without colchicine treatment. The ventral magnocellular division of the paraventricular nucleus contained fewer and less densely stained cells (Fig. 12). Medium-diameter fibers were demonstrable in both normal and colchicine-treated animals but to a greater extent in the former.

Supraoptic nucleus. Within the boundaries of this nucleus only occasional neurons were discretely immunostained for CRF, except along the dorsal border where strongly immunostained cells were more frequently observed. However, coarsely beaded fibers were abundant throughout much of the neuropil.

Suprachiasmatic nucleus. CRF-immunostained fibers were present in modest numbers within this nucleus; however, no discretely stained cell bodies were observed.

Arcuate nucleus. Antiserum to CRF stained a narrow arrangement of arcuate neurons which extended ventrally from the base of ventricle III in an inverted arc through immunostained fibers entering the median eminence at its lateral border (Figs. 14 and 15). Dendrites of the arcuate cells appeared to mingle with the fibers projecting to the median eminence (Fig. 15).

Median eminence. A dense network of intensely stained, CRF-immunoreactive fibers was present in the external layer of the median eminence abutting the hypothalamo-hypophyseal portal capillaries. Fewer fibers were visible in the internal layer. The median eminence and the parvocellular paraventricular region were equivalent in their high level of CRF immunoreactivity (Fig. 11). Finely beaded fibers containing CRF immunoreactivity entered the median eminence from its lateral aspect (Figs. 11, 14, and 15).

Mamillary nuclei. Oval cells of a medium size were lightly to well stained after incubation with antiserum to $\mathrm{CRF}$, and extended from the ventral premamillary to lateral mamillary nucleus and from dorsal premamillary to medial mamillary nucleus. Fibers, although present, were few and scattered.

Other hypothalamic nuclei. Scattered CRF-immunoreactive cells were located within the anterior (Figs. 9 and 10), lateral, dorsomedial, and ventromedial hypothalamic nuclei.

\section{Mesencephalon}

Nucleus raphe dorsalis. CRF-immunostained cells in this nucleus varied from round to elongate in profile. Staining intensity ranged from moderate to strong. Cells and fibers extended rostrally in a column from the dorsal raphe area into the regions of nucleus linearis rostralis and the Edinger-Westphal complex, lying medial and 

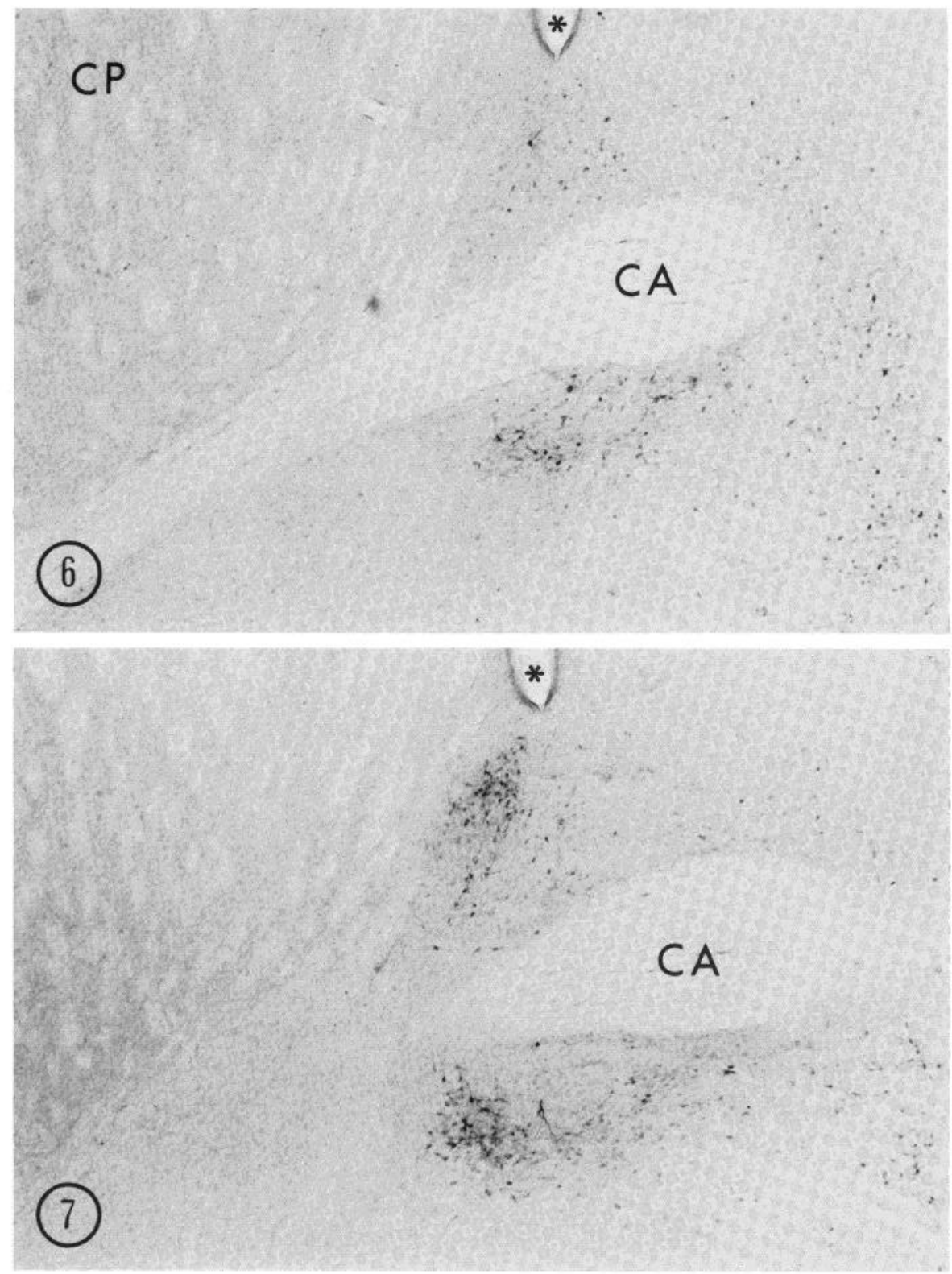

Figure 6 to 8 . Immunoperoxidase photomicrographs of CRF immunoreactivity in a rostral-caudal series of the anterior commissural $(C A)$ region of a colchicinetreated rat. CRF-immunoreactive neurons of the bed nucleus of stria terminalis surround the commissural fibers. Medially, immunostained cells appear to mingle with those of the anterior preoptic nucleus. *, lateral ventricle; $C P$, caudate putamen; $G P$, globus pallidus. Magnification $\times 44$.

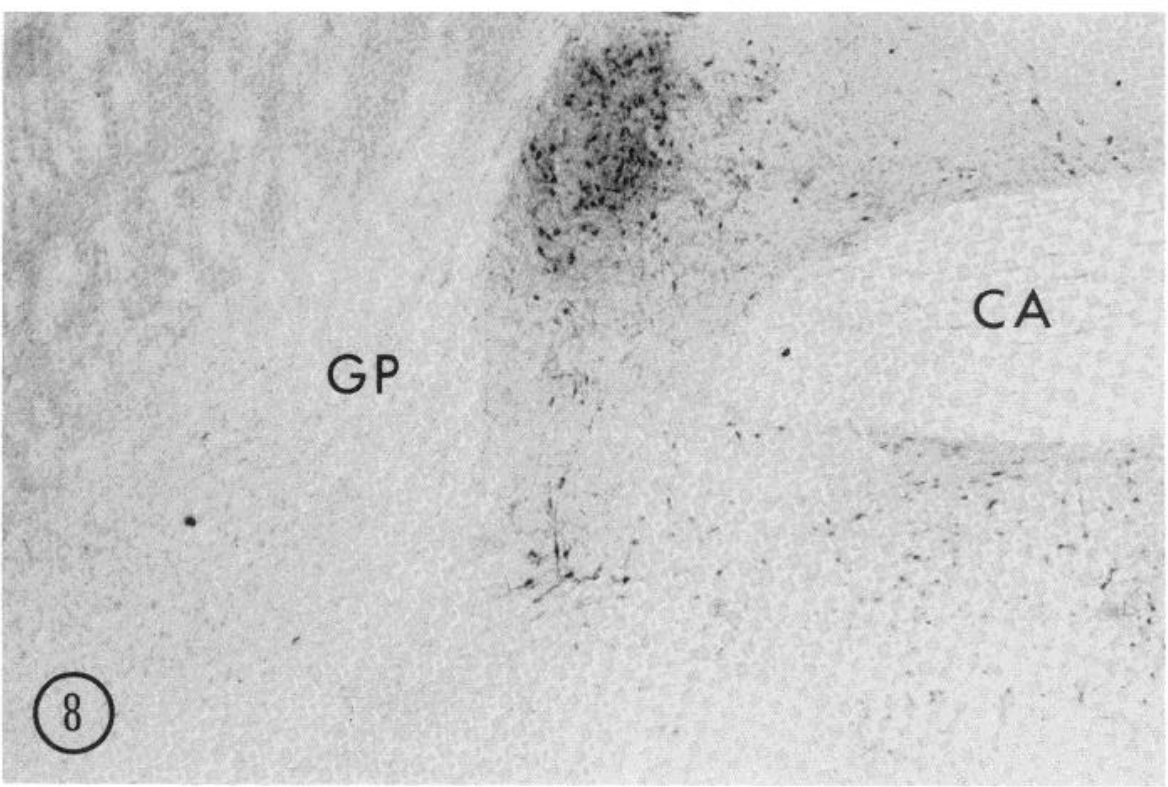



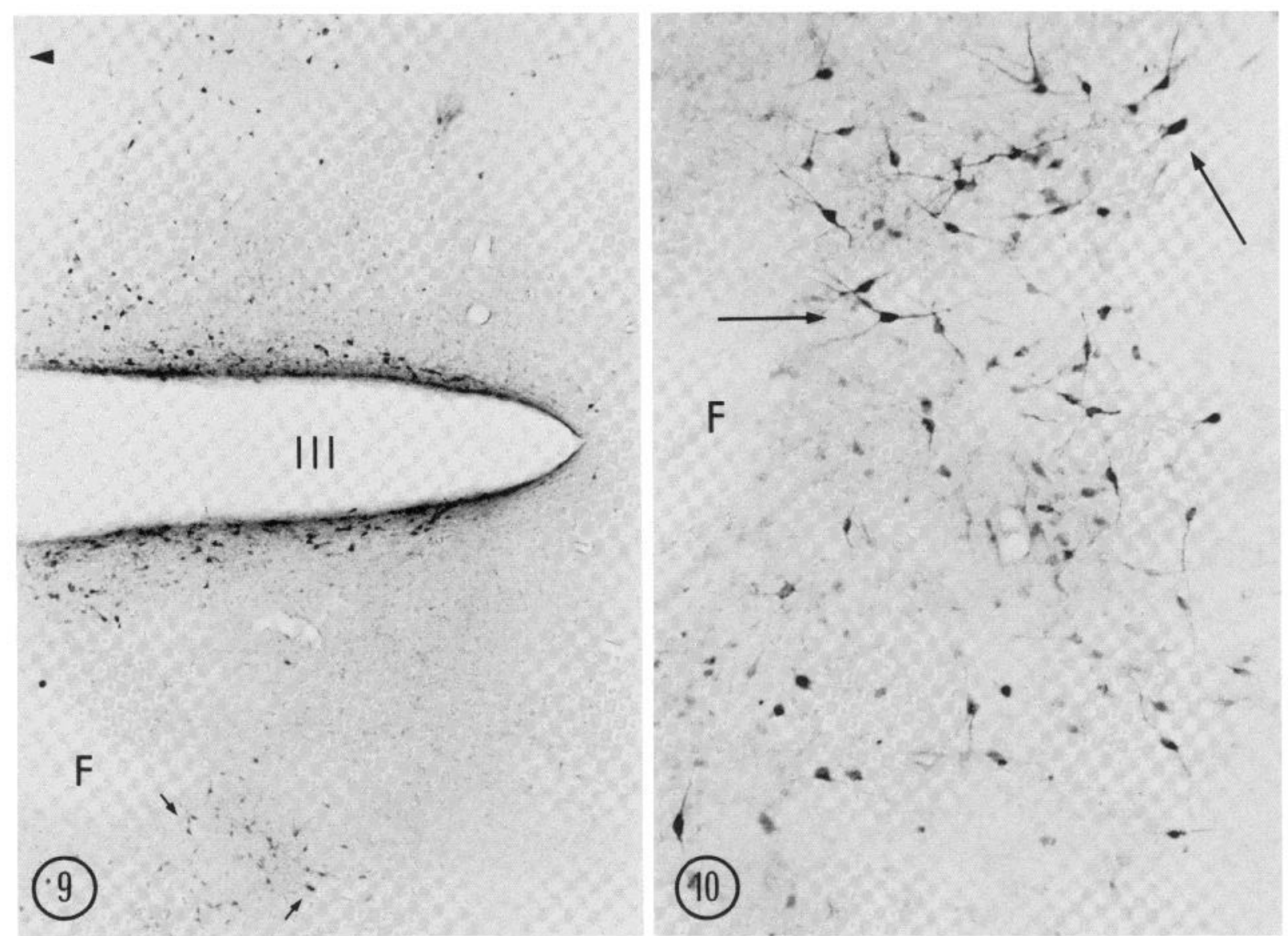

Figures 9 and 10. Immunoperoxidase photomicrographs of CRF-immunostained neurons within the narrow periventricular nucleus (Fig. 9) and the anterior hypothalamic area (Figs. 9 and 10) of a colchicine-treated rat. Figure 10 is a higher magnification of the anterior hypothalamic area seen in Figure 9. Arrows (Fig. 10) indicate the same neurons seen in Figure 9 and illustrate the typical pyramidal and elongated CRF-positive cells within the anterior hypothalamic region. Arrowhead, dorsal; $F$, fornix; III, ventricle III. Magnifications: Figure 9, × 44; Figure 10, × 110.

dorsomedial to the oculomotor nuclei and the medial longitudinal fasiculii (Fig. 17).

Periaqueductal gray. Although there were only a few faintly stained CRF-immunoreactive cells in the periaqueductal gray, many medium-diameter, beaded fibers were present ventrolaterally with respect to the aqueduct (Fig. 22).

\section{Pons}

Nucleus of the lateral lemniscus. The small, loose, CRF-immunoreactive cell cluster in this region consisted of lightly stained, predominantly elongated to rounded neurons.

Parabrachial nuclei. A compact cluster of ovoid neurons within the medial aspect of the lateral parabrachial nucleus was moderately stained after incubation with antiserum to CRF (Fig. 18). Immunostained fibers were apparent in both the lateral and medial parabrachial nuclei (Figs. 18 and 23).

Locus ceruleus. Moderately stained, elongated CRFimmunoreactive cells appeared in both the dorsal and ventral divisions of the locus ceruleus along the middle of its rostral-caudal extent. The immunostained cells were sparse in the dorsal division, but in the ventral division they formed a loosely packed aggregation just medial to the mesencephalic nucleus of the trigeminal nerve. The cells appeared bipolar or with few dendrites, oriented largely dorsoventrally (Fig. 16). More caudally, locus ceruleus neurons located at the lateral extent of ventricle IV, medial to the superior vestibular nucleus, stained less intensely.

\section{Medulla oblongata}

Reticular nuclei. A few densely stained, elongated or multipolar CRF-immunoreactive cells were sparsely distributed throughout the subtrigeminal portion of the lateral reticular nucleus and on the border between the nucleus of the spinal tract of the trigeminal nerve and nucleus reticularis parvocellularis (Figs. 20 and 21).

Lateral cuneate nucleus. Moderately CRF-immunoreactive cells were scattered within this nucleus (Fig. 19).

Inferior olive. A moderately dense network of fine- to medium-diameter fibers within the medial accessory division of this complex was immunostained after incubation with CRF antiserum (Fig. 25).

\section{Cerebellum}

Cerebellar fibers exhibiting CRF immunoreactivity extended the full width of the molecular layer of the flocculus. The fibers differed from those of other areas in being of a fine diameter with round, fairly regularly 


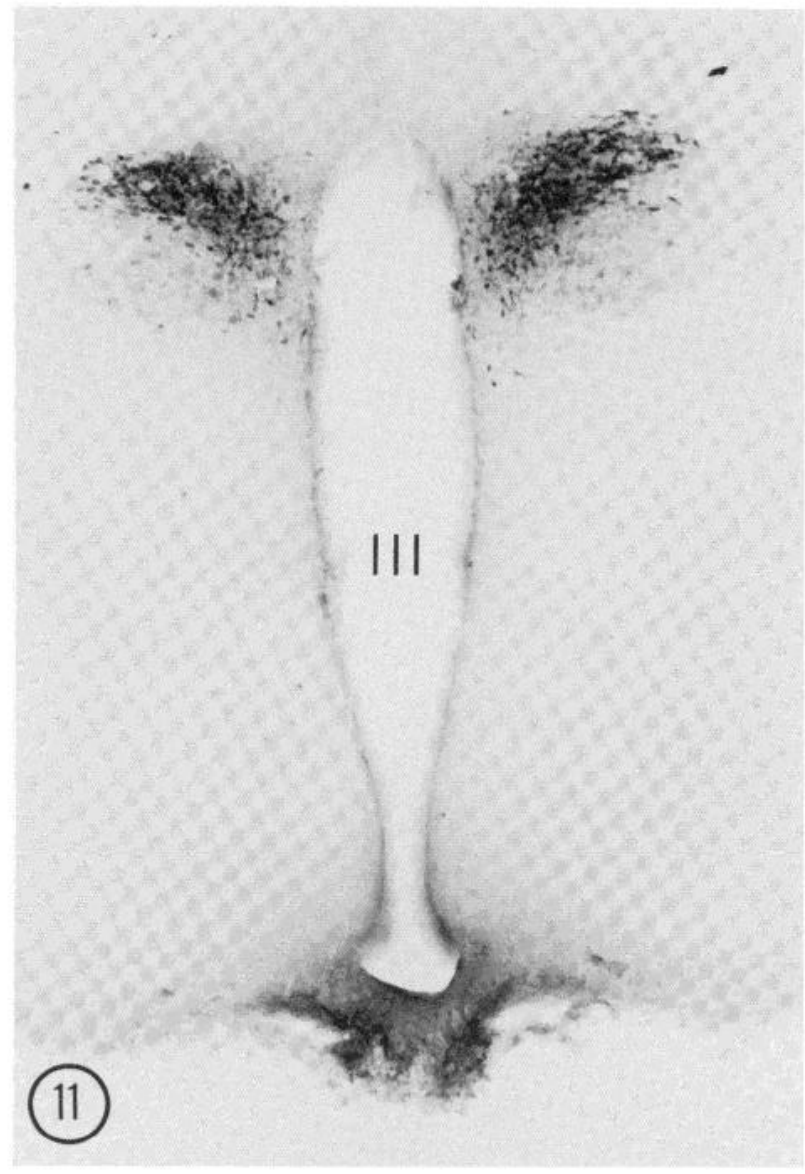

Figure 11. Photomicrograph of CRF-immunoperoxidasestained coronal section at the level of the intensely positive paraventricular nucleus and median eminence of a colchicinetreated rat. The external layer of the median eminence is more intensely CRF immunostained than the internal layer. III, ventricle III. Magnification $\times 46$. spaced varicosities. The fibers appeared to terminate in basket-like configurations opening toward the pial surface (Fig. 24).

\section{Discussion}

Attempts to chemically characterize CRF over the past three decades have, on several occasions, suggested that certain molecules fulfilled this role (reviewed by Yasuda et al., 1982). The recent characterization of a 41-amino acid peptide (Spiess et al., 1981; Vale et al., 1981) with potent in vitro and in vivo ACTH- and $\beta$-endorphinreleasing activity (Turkelson et al., 1981; Rivier et al., 1982; Sueiras-Diaz et al., 1982) may well represent the end of this search and signal the opportunity to investigate the role of the bona fide hypophysiotropic hormone in neuroendocrine regulation. The present study, which reports the localization of CRF immunoreactivity in fibers and terminals in the external layer of the hypothalamic median eminence and its occurrence in neuronal perikarya known to project to this region, adds further evidence to the argument that this peptide, or an immunochemically related molecule, is a physiological regulator of anterior pituitary function. This conclusion is based on the notion, first proposed by Harris (1948), that hypothalamic regulators of anterior pituitary hormone release are delivered by a neurohemal juxtaposition of nerve terminals with vascular elements of the hypothalamo-hypophyseal portal system. Previously characterized hypophysiotropic hormones have been reported to exist in dense plexuses of nerve fibers and terminals in the external layer of the median eminence (reviewed in Elde and Hökfelt, 1979). The present report, as well as recent reports of others (Bloom et al., 1982; Bugnon et al., 1982a, b; Paull et al., 1982; Tramu and Pillez, 1982), indicates an analogous neurohemal arrangement of CRFimmunoreactive fibers.

The cellular origin of CRF-immunoreactive fibers and

Figures 12 to 15. Immunoperoxidase micrographs of coronal sections of hypothalamic regions from colchicine-treated rats after incubation with antiserum to CRF (Figs. 12, 14, and 15) and with control CRF-absorbed serum (Fig. 13). The arrowhead and small arrow (upper left) indicate dorsal and medial, respectively.

Figure 12. Neurons of the paraventricular nucleus stained for CRF immunoreactivity. Open arrows indicate the boundary between the dorsal parvocellular and ventral magnocellular regions. Note that many cells of the former are intensely stained, whereas neurons in the latter division are more faintly stained. Magnification $\times 110$.

Figure 13. After incubation with control CRF-absorbed serum, no immunoreactive cells or fibers could be seen in the paraventricular nucleus in a tissue section adjacent to that in Figure 12. Magnification $\times 110$.

Figure 14. A dense network of intensely stained CRF-immunoreactive fibers in the external layer of the median eminence. Fewer CRF-immunostained fibers were present in the internal layer. Narrow arrowheads indicate fine fibers entering the median eminence. Large arrows indicate cells within the arcuate nucleus. III, ventricle III; *, capillary of the hypothalamo-hypophyseal portal plexus. Magnification $\times 112$.

Figure 15. Arcuate nucleus. The large arrow indicates CRF-immunoreactive neuron with dendrites extending into the vicinity of fibers projecting toward the median eminence. Narrow arrowheads indicate fine diameter CRF-immunoperoxidase-stained beaded fibers entering the median eminence. Magnification $\times 220$.

Figures 16 to 19. Photomicrographs of CRF-immunoperoxidase-stained coronal sections within brainstem regions of colchicinetreated rats. The arrowhead and small arrow (upper left) indicate dorsal and medial, respectively.

Figure 16. Many CRF-immunoreactive cells were present within the ventral division of locus ceruleus. Fewer, elongated cells with dorsoventrally oriented dendrites were present in the dorsal division. Light asterisk, mesencephalic nucleus of trigeminal nerve; heavy asterisk, mesencephalic tract of trigeminal nerve; $I V$, ventricle IV. Magnification $\times 125$.

Figure 17. CRF-immunoreactive cells at the intersection of nucleus raphe dorsalis with the region of nucleus linearis rostralis and the Edinger-Westphal complex. $O C$, oculomotor nucleus. Magnification $\times 110$.

Figure 18. Parabrachial nucleus. CRF-immunoreactive cells clustered in the medial part of the lateral parabrachial nucleus. Fibers were also present in medial parabrachial nucleus. TSC, spinocerebellar tract; $B C$, brachium conjunctivium; *, mesencephalic nucleus and tract of trigeminal nerve. Magnification $\times 110$.

Figure 19. Lateral cuneate nucleus. CRF-immunostained cells were distributed in a longitudinal column within the dorsal medulla. ICP, inferior cerebellar peduncle; TST, spinal tract of trigeminal nerve. Magnification $\times 110$. 


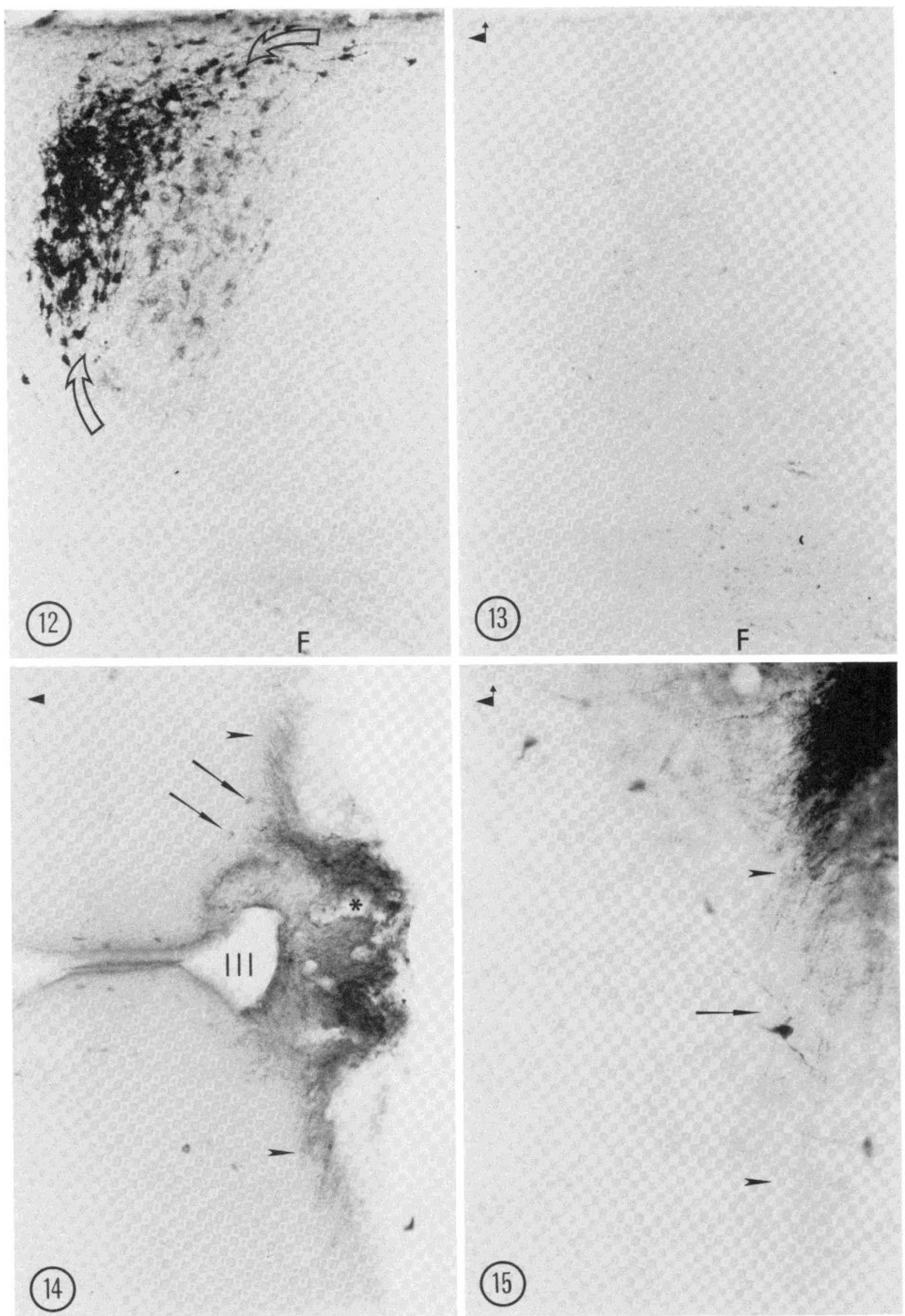



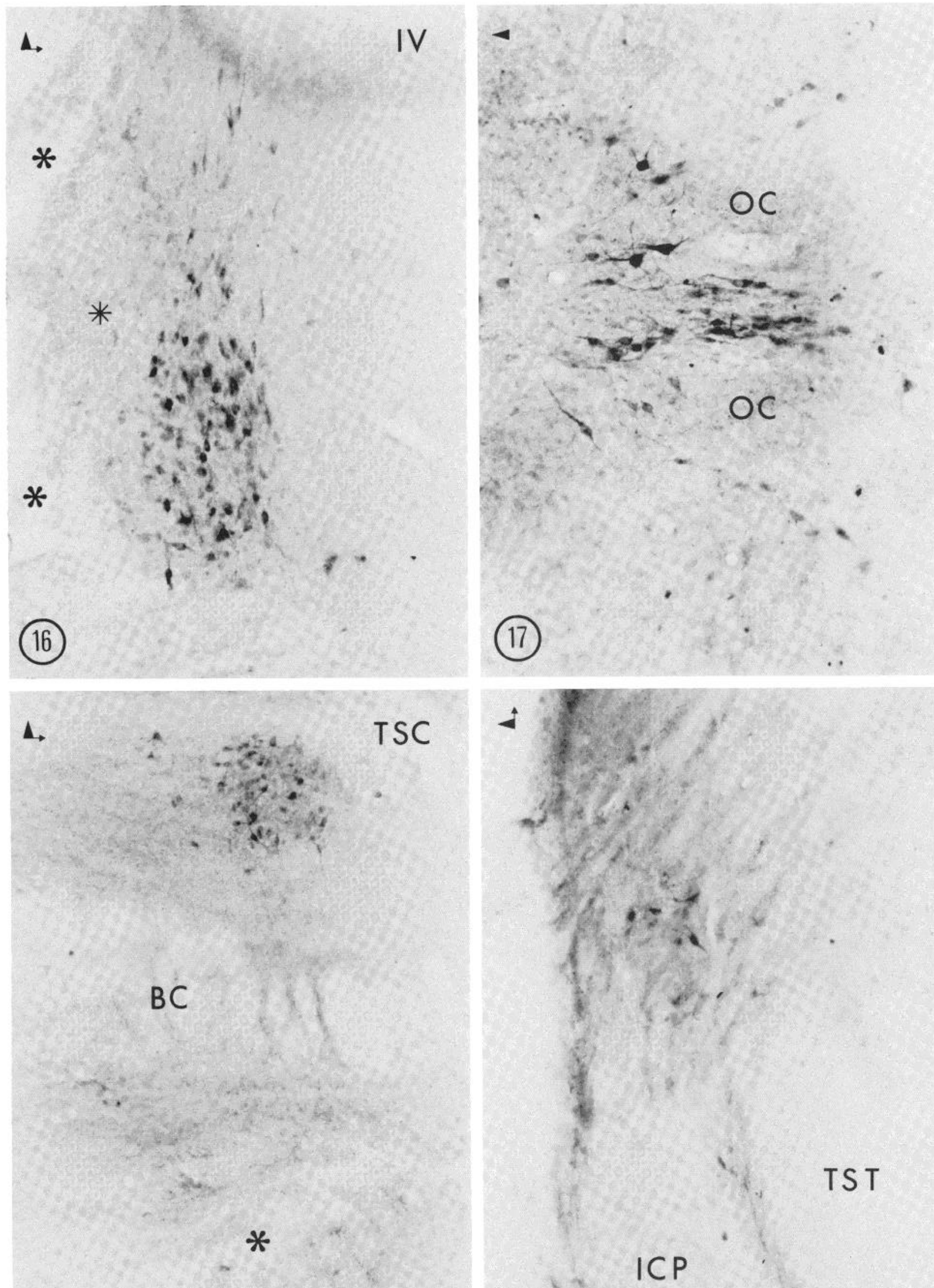

(18)

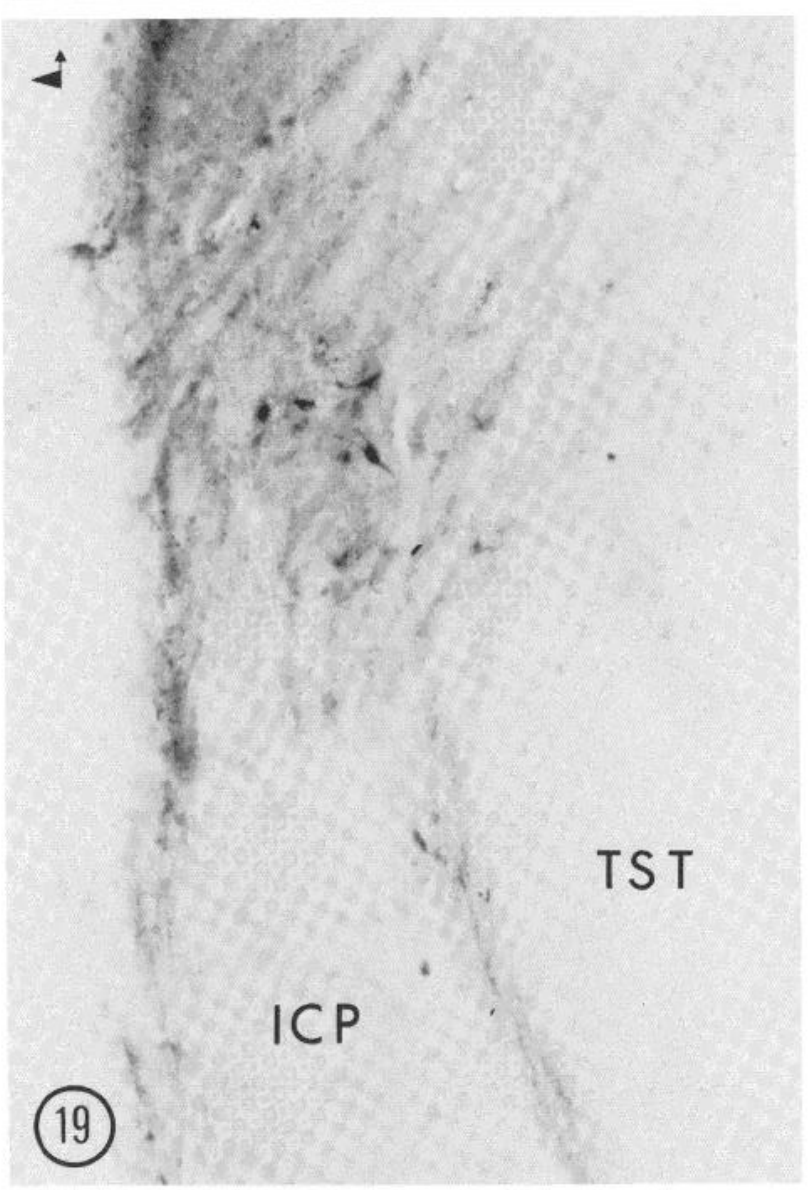



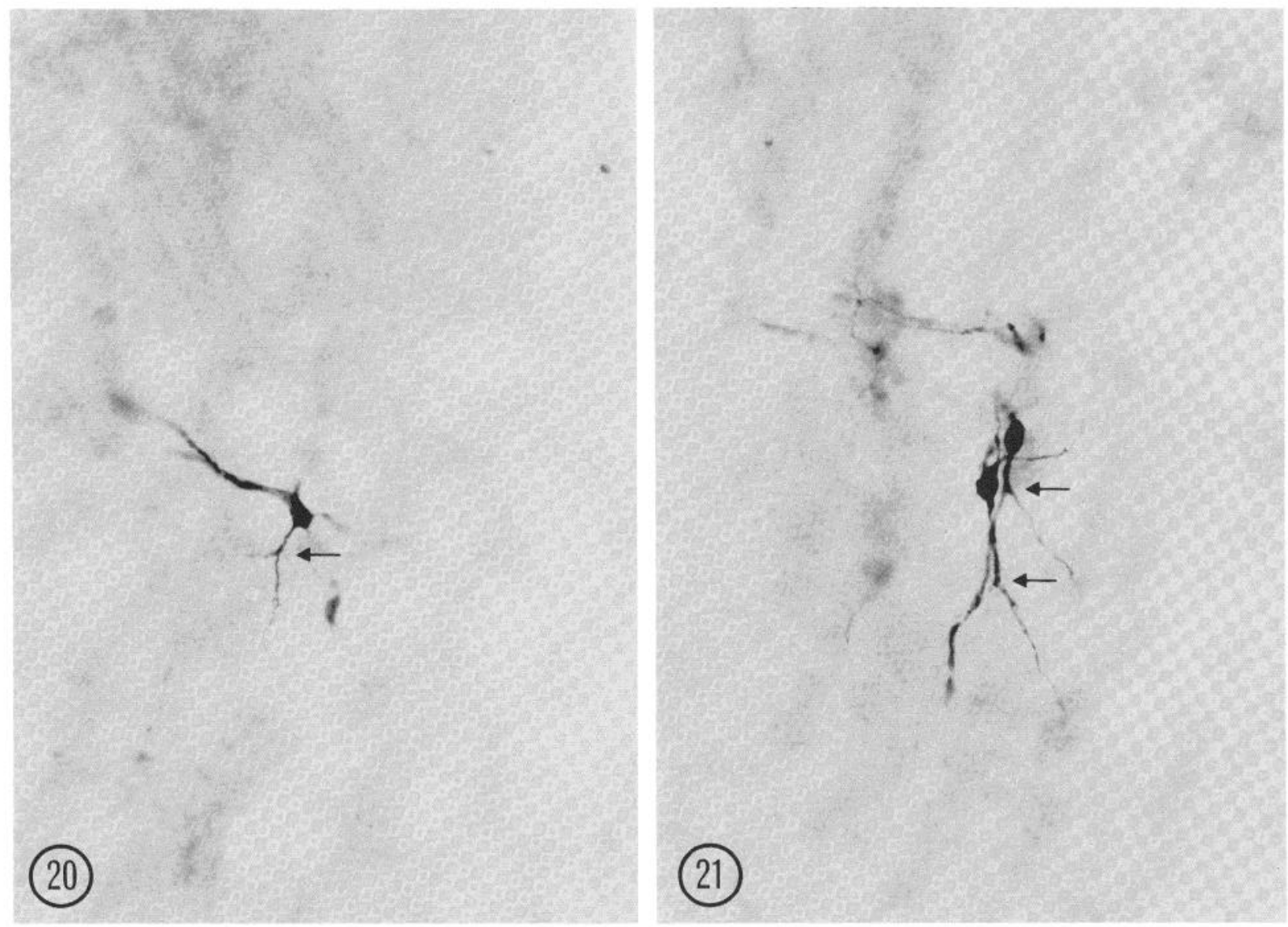

Figures 20 and 21. Photomicrographs of CRF-immunoperoxidase-stained neurons within different areas of the same coronal section. Small arrows indicate branching of primary dendrites into secondary dendrites.

Figure 20. Cell located on the medial border of nucleus reticularis parvocellularis adjacent to the spinal tract of the trigeminal nerve. Magnification $\times 220$.

Figure 21. Cells within the subtrigeminal portion of the lateral reticular nucleus at the same level as Figure 20. Magnification $\times 225$.

terminals in the external layer of the median eminence was not experimentally determined in the present study, although it is likely to arise from the numerous CRFimmunoreactive perikarya in the hypothalamic paraventricular (Figs. 11 and 12), periventricular (Fig. 9), and supraoptic nuclei, because these nuclei have been reported to project prominently to the median eminence (Wiegand and Price, 1980; Swanson and Kuypers, 1980; Alonso, 1981). An additional, although less prominent, source of CRF-immunoreactive fibers in the external layer of the median eminence might arise from the CRFimmunoreactive perikarya found in the hypothalamic arcuate nucleus (Figs. 14 and 15). The occurrence of CRF immunoreactivity within large numbers of neurons of the paraventricular nucleus strongly suggests coexistence of the CRF-like molecule with peptides previously reported to exist within these neurons, including oxytocin, vasopressin (Elde, 1973; Burlet et al., 1974; Vandesande and Dierickx, 1975; Zimmerman, 1976), and dynorphin (Watson et al., 1982). Our previous studies have suggested that vasopressin may participate in regulation of ACTH release (Seybold et al., 1981), a suggestion that remains intriguing because of the distribution of CRF immunoreactivity and the recent study demonstrating potentiation of synthetic CRF's effects by vasopressin (Turkelson et al., 1982).

Similar to other hypophysiotropic hormones, CRF immunoreactivity seems to exist in diverse neuronal systems that are unlikely to act as neuroendocrine regulators. Thus, in the present study, neuronal perikarya

Figures 22 to 25 . Immunoperoxidase photomicrographs of coronal sections from normal rats after incubation with antiserum to CRF. The arrowhead and small arrow (upper left) indicate dorsal and medial, respectively.

Figure 22. CRF-immunoreactive fiber studded with varicosities within ventrolateral periaqueductal gray. Magnification $\times 440$.

Figure 23. CRF-immunoreactive fibers within lateral parabrachial nucleus. Magnification $\times 440$.

Figure 24. CRF-immunoreactive fibers within the molecular layer of the floccular lobe of the cerebellum. Varicosities were regularly sized and spaced. The asterisk is within basket-like fiber termination. Narrow arrowheads indicate pial surface. Magnification $\times 440$.

Figure 25. CRF-immunoreactive fibers within medial accessory division of the inferior olivary complex. Magnification $\times 220$. 

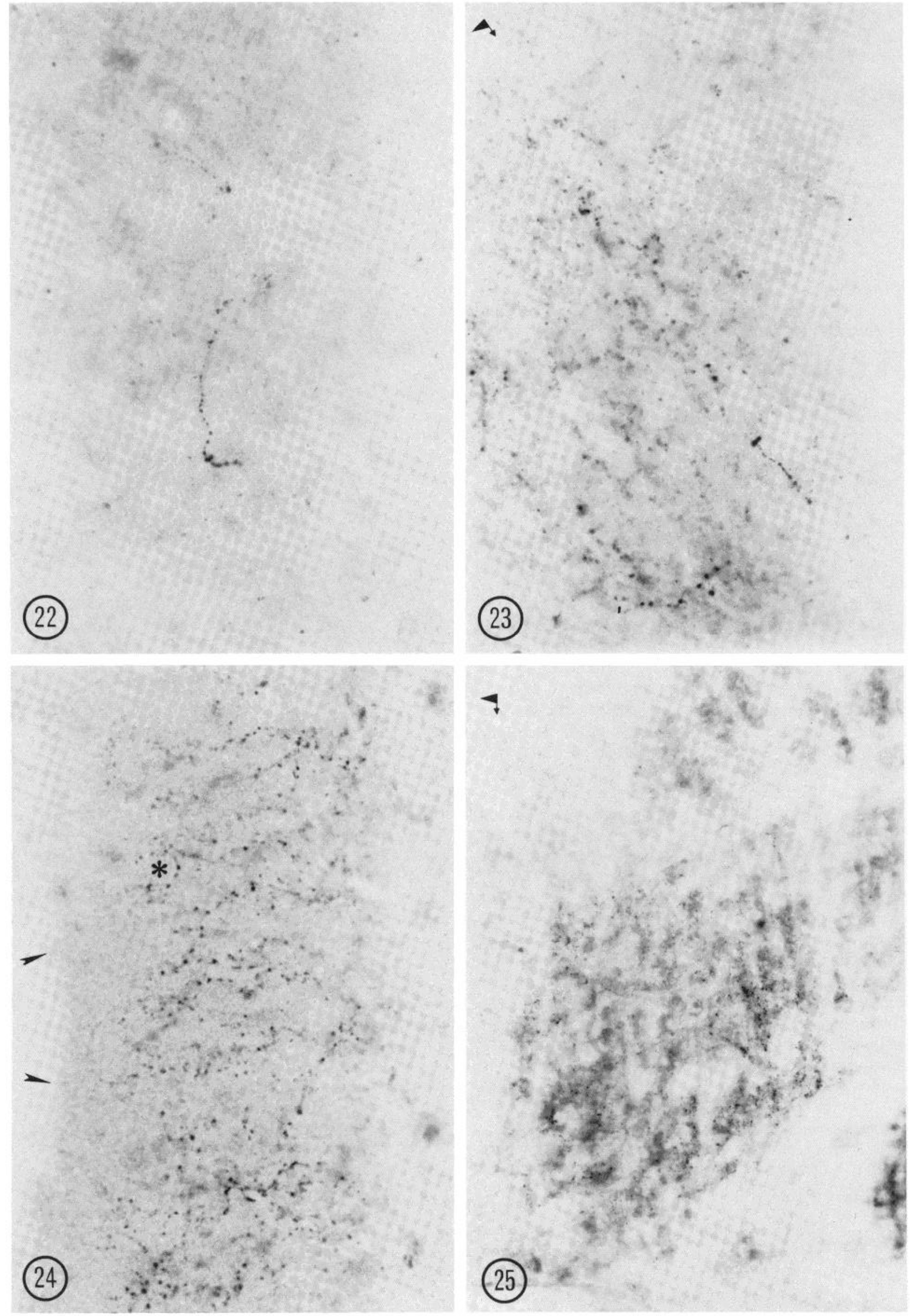

Figures 22 to 25 
containing CRF immunoreactivity were widely distributed, ranging from rostral regions of the telencephalon to caudal portions of the medulla oblongata.

Telencephalic neurons containing CRF immunoreactivity were prominent in the central nucleus of the amygdala, a region notable for the large number of peptidergic elements it contains (Hökfelt et al., 1978; Roberts et al., 1982). Similarly striking were the numerous neurons of the bed nucleus of the stria terminalis which contained a CRF-like molecule. Although these regions may indirectly influence endocrine function via multisynaptic pathways, it is likely that the putative CRF-like substance released from the terminals of these neurons serves to regulate the activity of other neurons. It is of interest to note that administration of synthetic CRF into the lateral ventricle of the rat has been shown to produce locomotor activation and behavior consistent with an increase in "emotionality" (Sutton et al., 1982) as well as an alteration in behavioral responses to a novel environment (Britton et al., 1982). It is plausible that such behavior is induced by activation of putative CRF receptors in the forebrain upon which the nerve terminals of the CRF-immunoreactive cell bodies residing in the amygdala and bed nucleus of the stria terminalis impinge.

CRF-immunoreactive perikarya were also prominent in several hrainstem regions. CRF-immunostained cells in the mesencephalon were found in the rostral portion of nucleus raphe dorsalis and continued rostrally into the vicinity of the nucleus linearis rostralis and the EdingerWestphal complex. Some of these neurons, especially those residing within nucleus raphe dorsalis per se, are likely to co-contain the CRF-like substance along with serotonin, although such coexistence remains to be verified. It should be noted that previous studies have demonstrated the coexistence of peptides such as enkephalin in a subpopulation of serotonergic dorsal raphe neurons (Glazer et al., 1981). CRF immunoreactivity might be found to coexist with acetylcholine in preganglionic parasympathetic neurons of the Edinger-Westphal complex, although it is clear that many neurons of this complex may not be preganglionic with respect to the parasympathetic nervous system and, therefore, may not be cholinergic (see Loewy and Saper, 1978).

Coexistence of CRF immunoreactivity with norepinephrine in neurons of locus ceruleus may also be demonstrated, because our studies revealed a group of neurons ventrally disposed within locus ceruleus to exhibit CRF immunoreactivity. Further support of such coexistence, although not directly established, may be adduced from the distribution of CRF-immunoreactive fibers and terminals within known target areas of the locus ceruleus, for example, the inferior olivary complex and the cerebellum.

Investigators have reported that intraventricular administration of synthetic CRF elevates mean arterial pressure and heart rate (Fisher et al., 1982), as well as producing hyperglycemia and increases in plasma glucagon, epinephrine, and norepinephrine (Brown et al., 1982a, b), presumably through centrally mediated autonomic control mechanisms. The present study, in part, suggests that endogenous CRF may participate in such autonomic regulation, perhaps via CRF-immunoreactive neurons in the lateral parabrachial nucleus (Fig. 18) or the medullary reticular formation (Figs. 20 and 21), inasmuch as neurons from these areas are known to be active in cardiovascular control. Furthermore, our preliminary studies of rat and particularly sheep spinal cord indicate prominent CRF-immunoreactive elements in the vicinity of the intermediolateral cell column as well as in other brainstem autonomic centers. Many of these fibers may be derived from the striking population of CRFimmunoreactive neurons in the parvocellular division of the paraventricular nucleus, because it has been shown to project caudally to these sites (Swanson and Kuypers, 1980).

The exact molecular nature of CRF immunoreactivity within the rat brain revealed in our studies remains uncharacterized. Specificity (absorption control) experiments indicated that the staining we obtained represents immunochemically similar antigenic determinants compared to those found on the 41-amino acid peptide identified as CRF from ovine hypothalamic extracts. Several other investigators have recently reported, in studies restricted to the hypothalamus, a similar distribution of CRF immunoreactivity, using independently generated antisera to the 41-amino acid ovine peptide (Bloom et al., 1982; Bugnon et al., 1982a, b; Tramu and Pillez, 1982) or to fragments thereof (Paull et al., 1982). The concordance of these and the present study also supports the specificity of the localization of CRF.

However, we have noted that immunostaining of neurons in the sheep brain with the present CRF antiserum provides much more intense and widespread specific staining than we have observed in rat brain. This may suggest that the version of CRF synthesized by rat is somewhat different from that of the sheep. Nevertheless, the distribution of CRF immunoreactivity reported herein is likely to represent, perhaps incompletely, the distribution of rat CRF, because all areas positive in rat brain were more intensely positive in sheep brain (S. Cummings and R. Elde, unpublished data). However, confirmation of this suggestion must await the availability of antiserum specifically directed against the rat version of CRF.

Note added in proof. Additional findings relevant to this investigation have recently become available (Paull and Gibbs, 1983; Swanson et al., 1983).

\section{References}

Alonso, G. (1981) Etudes morphologiques et fonctionnelles des neurones neurosecretoires hypothalamo-neurohypophysaires chez le rat. Thesis, Academie de Montpellier, Universite des Sciences et Techniques du Languedoc.

Berod, A., B. K. Hartman, and J. F. Pujol (1981) Importance of fixation in immunohistochemistry: Use of formaldehyde solutions at variable $\mathrm{pH}$ for the localization of tyrosine hydroxylase. J. Histochem. Cytochem. 29: 844-850.

Bloom, F. E., E. L. F. Battenberg, J. Rivier, and W. Vale (1982) Corticotropin releasing factor (CRF): Immunoreactive neurones and fibers in rat hypothalamus. Regul. Peptides 4: 4348.

Britton, D. R., G. F. Koob, J. Rivier, and W. Vale (1982) Intraventricular corticotrophin-releasing factor cnhances bchavioral effects of novelty. Life Sci. 31: 363-367. 
Brown, M. R., L. A. Fisher, J. Rivier, J. Spiess, C. Rivier, and W. Vale (1982a) Corticotropin-releasing factor: Effects on the sympathetic nervous system and oxygen consumption. Life Sci. 30: 207-210.

Brown, M. R., L. A. Fisher, J. Spiess, C. Rivier, J. Rivier, and W. Vale (1982b) Corticotropin-releasing factor: Actions on the sympathetic nervous system and metabolism. Endocrinology 111: 928-931.

Bugnon, C., D. Fellmann, A. Gouget, and J. Cardot (1982a) Etude immunocytochemique de l'ontogenese du systeme neuroglandulaire a CRF chez le Rat. C. R. Acad. Sci. Paris Serie III 294: 599-604.

Bugnon, C., D. Fellmann, A. Gouget, and J. Cardot (1982b) Ontogeny of the corticoliberin neuroglandular system in rat brain. Nature 298: 159-161.

Burlet, A., J. Marchetti, and J. Duheille (1974) Immunohistochemistry of vasopressin: Study of the hypothalamo-hypophysial system of normal, dehydrated and hypophysectomized rats. In Neurosecrelion-The Final Neuroendocrine Pathway, F. Knowles and L. Vollrath, eds., pp. 24-30, Springer-Verlag, Berlin.

Cummings, S., R. Elde, J. Ells, and A. Lindall (1982) Corticotropin releasing factor (CRF) localization in the rat brain. Soc. Neurosci. Abstr. 8: 110.

Elde, R. P. (1973) Methods for the localization of vasopressincontaining neurons in the hypothalamus and pars nervosa by immunoenzyme histochemistry. Anat. Rec. 175: 313.

Elde, R. and T. Hökfelt (1979) Localization of hypophysiotropic peptides and other biologically active peptides within the brain. Annu. Rev. Physiol 41: 587-602.

Fischman, A. J., and R. L. Moldow (1982) Extrahypothalamic distribution of CRF-like immunoreactivity in the rat brain. Peptides 1: 149-153.

Fisher, L. A., J. Rivier, C. Rivier, J. Spiess, W. Vale, and M. R. Brown (1982) Corticotropin-releasing factor (CRF): Central effects on mean arterial pressure and heart rate in rats. Endocrinology 6: 2222-2224.

Glazer, E. J., H. W. M. Steinbusch, A. A. J. Verhofstad, and A. I. Basbaum (1981) Serotonin neurons in nucleus raphe dorsalis and paragiganto-cellularis of the cat contain enkephalin. J. Physiol (Paris) 77: 241-245.

Grossman, A., L. Perry, A. V. Schally, L. H. Rees, A. C. Nieuwenhuyzen Kruseman, S. Tomlin, D. H. Coy, A.-M. Comaru-Schally, and G. M. Besser (1982) New hypothalamic hormone, corticotropin-releasing factor, specifically stimulates the release of adrenocorticotropic hormone and cortisol in man. Lancet 1: 921-922.

Grzanna, R., and M. E. Molliver (1980) The locus coeruleus in the rat: An immunohistochemical delineation. Neuroscience 5: $21-40$.

Grzanna, R., M. E. Molliver, and J. T. Coyle (1978) Visualization of central noradrenergic neurons in thick sections by the unlabeled antibody method: A transmitter-specific Golgi image. Proc. Natl. Acad. Sci. U. S. A. 75: 2501-2506.

Guillemin, R., and B. Rosenberg (1955) Humoral hypothalamic control of anterior pituitary: A study with combined tissue cultures. Endocrinology 75: 599-607.

Haber, S., and R. Elde (1982) The distribution of enkephalin immunoreactive fibers and terminals in the monkey central nervous system: An immunohistochemical study. Neuroscience 5: 1049-1095.

Harris, G. W. (1948) Neural control of the pituitary gland. Physiol. Rev. 28: 139-179.

Hökfelt, T., R. P. Elde, O. Johansson, Å. Ljungdahl, M. Schultzberg, K. Fuxe, M. Goldstein, G. Nilsson, B. Pernow, L. Terenius, D. Ganten, S. L. Jeffcoate, J. Rehfeld, and S. Said (1978) The distribution of peptide containing neurons in the nervous system. In Psychopharmacology: A Generation of
Progress, K. Killam, M. Linton, and A. DiMascio, eds., pp. 36-66, Raven Press, New York.

King, G. W. (1980) Topology of ascending brainstem projections to nucleus parabrachialis in the cat. J. Comp. Neurol. 191: 615-638.

Kohler, C., and H. Steinbusch (1982) Identification of serotonin and nonserotonin-containing neurons of the mid-brain raphe projecting to the entorhinal area and the hippocampal formation. A combined immunohistochemical and fluorescent retrograde tracing study in the rat brain. Neuroscience 7 : 951-975.

König, J. F. R., and R. A. Klippel (1967) The Rat Brain. A Stereotaxic Atlas of the Forebrain and Lower Parts of the Brain Stem, Robert E. Krieger Publishing Co., Inc., Huntington, NY.

Larsson, L. -I. (1981) A novel immunocytochemical model system for specificity and sensitivity of antisera against multiple antigens. J. Histochem. Cytochem. 29: 408-410.

Loewy, A. D., and C. B. Saper (1978) Edinger-Westphal nucleus: Projections to the brain stem and spinal cord in the cat. Brain Res. 150: 1-27.

McDonald, A. (1982) Cytoarchitecture of the central amygdaloid nucleus of the rat. J. Comp. Neurol. 208: 401-418.

Moldow, R. L., and A. J. Fischman (1982) Hypothalmic CRFlike immunoreactivity in the rat after hypophysectomy or adrenalectomy. Peptides 1: 143-147.

Nieuwenhuys, R., L. M. G. Geeraedts, and J. G. Veening (1982) The medial forebrain bundle of the rat. I. General introduction. J. Comp. Neurol. 206: 49-81.

Paull, W. K., and F. P. Gibbs (1983) The corticotropin releasing factor (CRF) neurosecretory system in intact, adrenalectomized, and adrenalectomized-dexamethasone treated rats: An immunocytochemical analysis. Histochemistry, in press.

Paull, W. K., J. Scholer, A. Arimura, C. A. Meyers, J. K. Chang, D. Chang, and M. Shimizu (1982) Immunocytochemical localization of CRF in the ovine hypothalamus. Peptides 1 : 183-191.

Pellegrino, L. J., A. S. Pellegrino, and A. J. Cushman (1979) A Stereotaxic Atlas of the Rat Brain, Ed. 2, Plenum Publishing Corp., New York.

Rivier, C., M. Brownstein, J. Spiess, J. Rivier, and W. Vale (1982) In vivo corticotropin-releasing factor-induced secretion of adrenocorticotropin, $\beta$-endorphin and corticosterone. Endocrinology 110: 272-278.

Roberts, G. W., P. L. Woodhams, J. M. Polak, and T. J. Crow (1982) Distribution of neuropeptides in the limbic system of the rat: The amygdaloid complex. Neuroscience $7: 99-131$.

Saffran, M., and A. V. Schally (1955) The release of corticotropin by anterior pituitary tissue in vitro. Can. J. Biochem. Physiol. 33: 408-415.

Sakai, K., M. Rouret, D. Salvert, and M. Jouvet (1978) Afferents to the cat locus ceruleus and rostral raphe nuclei as visualized by the horseradish peroxidase technique. In Interactions Between Putative Neurotransmitters in the Brain, S. Garattini, J. F. Pujol, and R. Samanin, eds., pp. 319-342, Raven Press, New York.

Sawchenko, P. E., and L. W. Swanson (1982) Immunohistochemical identification of neurons in the paraventricular nucleus of the hypothalamus that project to the medulla or to the spinal cord in the rat. J. Comp. Neurol. 205: 260-272.

Seybold, V., R. Elde, and T. Hökfelt (1981) Terminals of reserpine-sensitive vasopressin-neurophysin neurons in the external layer of the rat median eminence. Endocrinology 108: 1803-1809.

Spiess, J., R. Rivier, C. Rivier, and W. Vale (1981) Determination of the primary structure of corticotropin releasing factor from ovine hypothalamus. Proc. Natl. Acad. Sci. U. S. A. 78: 6517. 
Sternberger, L. A. (1979) Immunocytochemistry, John Wiley \& Sons, New York.

Sueiras-Diaz, J., D. H. Coy, S. Vigh, T. W. Redding, W. Huang, I. Torres-Aleman, and A. V. Schally (1982) Synthesis and biological properties of ovine corticotropin-releasing factor (CRF). Life Sci. 31: 429-435.

Sutton, R. E., G. F. Koob, M. LeMoal, J. Rivier, and W. Vale (1982) Corticotropin releasing factor produces behavioural activation in rats. Nature 297: 331-333.

Swanson, L. W. (1976) The locus coeruleus: A cytoarchitectonic, Golgi and immunohistochemical study in the albino rat. Brain Res. 110: 39-56.

Swanson, L. W., and H. G. J. M. Kuypers (1980) The paraventricular nucleus of the hypothalamus: Cytoarchitectonic subdivisions and organization of projections to the pituitary, dorsal vagal complex, and spinal cord as demonstrated by retrograde fluorescence double-labeling methods. J. Comp. Neurol. 194: 555-570.

Swanson, L. W., P. E. Sawchenko, J. Rivier, and W. W. Vale (1983) Organization of ovine corticotropin-releasing factor immunoreactive cells and fibers in the rat brain: An immunohistochemical study. Neuroendocrinology 36: 165-186.

Tramu, G., and A. Pillez (1982) Localization immunohistochimique des terminaisons nerveuses a corticoliberin (GRF) dan l'eminence mediane du Cobaye et du Rat. C. R. Acad. Sci. Paris Serie III 294: 107.

Turkelson, C. M., C. R. Thomas, A. Arimura, D. Chang, J. K.
Chang, and M. Shimizu (1982) In vitro potentiation of the activity of synthetic ovine corticotropin-releasing factor by arginine vasopressin. Peptides 1: 111-113.

Vale, W., J. Spiess, C. Rivier, and J. Rivier (1981) Characterization of a 41 residue ovine hypothalamic peptide that stimulates the secretion of corticotropin and $\beta$-endorphin. Science 213: 1394

Valverde, F. (1962) Reticular formation of the albino rat's brain stem: Cytoarchitecture and corticofugal connections. J. Comp. Neurol. 119: 25-53.

Vandesande, F., and K. Dierickx (1975) Identification of the vasopressin producing and of the oxytocin producing neurons in the hypothalamic magnocellular neurosecretory system of the rat. Cell Tissue Res. 164: 153-162.

Watson, S. J., H. Akil, W. Fischli, A. Goldstein, E. Zimmerman, G. Nilaver, and 'T. B. van Wimersma Greidanus (1982) Dynorphin and vasopressin: Common localization in magnocellular neurons. Science 216: 85-87.

Wiegand, S. J., and J. L. Price (1980) Cells of origin of the afferent fibers to the median eminence in the rat. J. Comp. Neurol. 192: 1-19.

Yasuda, N., M. A. Greer, and T. Aizawa (1982) Corticotropinreleasing factor. Endocrine Rev. 3: 123-140.

Zimmerman, E. A. (1976) Localization of hypothalamic hormones by immunocytochemical techniques. In Frontiers of Neuroendocrinology, L. Martini and W. R. Ganong, eds., Vol. 4, pp. 25-62, Raven Press, New York. 